\title{
Promoting Knowledge of Sexual Illnesses among Women in Bangladesh: Can Non-Governmental Organizations Play a Role?
}

The participation of poor women in NGO-led community-based health forums can significantly improve the knowledge of sexual illnesses among women

By Abdullahel Hadi and Roxana Parveen *

The sexually transmitted infections (STIs) are significant causes of morbidity and mortality among women of reproductive age. Some of the STI-related complications not only result in spontaneous abortion, infertility, ectopic

* Abdullahel Hadi. Senior Research Sociologist, Bangladesh Rural Advancement Committee (BRAC), Dhaka. Bangladesh and Roxana Parveen, Training Coordinator. Population Services and Training Centre (PSTC). Dhaka.

Asia-Pacific Poulation Journal, March 2003 
pregnancy and cervical cancer, but common STIs can also cause long-term impairment of reproductive health and increase the risk of HIV transmission from one person to another (Cameron, Simonsen and D'Costa, 1989; Wasserheit, 1992; Population Information Program, 1993). It has been estimated that sexually transmitted infections and their complications collectively rank second in importance in the world among diseases in women of reproductive ages (World Bank, 1993). Ignorance and misinformation of sexual illnesses are often considered powerful barriers to resolving such health problems in the traditional communities (UNAIDS, 1998).

Among the types of sexual illnesses, the prevalence was found to be 18 per cent for gonorrhoea. 17 per cent for syphilis and 30 per cent for trichomoniasis in the developing countries (Population Information Program, 1993). Although sexual illnesses are major public health problems in the world. the prevalence rates are much higher in the developing than developed countries. According to the World Health Organization estimate, about 150 million new cases of sexual illnesses occurred in South-East Asia and 65 million in the sub-Saharan Africa in 1995 (UNAIDS, 1998). In a recent study, the prevalence of sexual illnesses was reported to be very high in Russia (Amirkhanian, Kelly and Issayev, 2001). Although the consequences of STIs are devastating, women suffer more than men and the overall response to control the problem is limited. It is now recognized that timely intervention and effective management can significantly reduce consequences of STIs (Population Information Program, 1993). Although the promotion of the knowledge of STI as the preventive measure has received priority, the level of awareness about the transmission, symptoms, consequences and prevention of sexual illnesses in the developing countries have been very low (Adekunle and Ladipo, 1992; Hillier and others, 1998; Castor and others, 2002).

The prevalence of sexually transmitted infections in Bangladesh is not clearly known. Available estimates show a wide variation of STI prevalence ranging from 2.5 to 23.2 per cent among women (Hussain and others, 1997; Hawkes and others, 1999). As sexual behaviour among young adults and adolescents has been changing. the scenario might have already been different than what has been known before. Recent studies indicate that STIs have been increasing among people who have sexual relationships with multiple partners (Khan and others, 1997). The Government has rightly identified sexually transmitted infections (STIs) as major public health problems in Bangladesh and prioritized them as one of the key component of reproductive health services. However, very little information is known about sexual illnesses among women 
of reproductive ages. One study, conducted in 1994, has shown that about 26.6 per cent of women were aware of sexual illnesses (Khan and others, 1997).

The need for preventing sexually transmitted infections and HIV/AIDS has increasingly been discussed in various forums in Bangladesh. A national policy was developed in early 1995 to prevent HIV transmission, reduce the impact of AIDS and manage STIs (Government of Bangladesh, 1996a and 1996b). The major features of the policy included advocacy at national level, behaviour change initiatives for higher-risk populations and campaign in the mass media (Government of Bangladesh, 1999). In 1997, the Government of Bangladesh formally accepted the principles adopted in the International Conference on Population and Development (ICPD) focussing on informing women about reproductive health problems and seeking early treatment wherever possible (United Nations, 1995; Government of Bangladesh, 1999). Since then, the need for developing behavioural change communication strategy and its implementation in preventing sexually transmitted infections has been discussed in various forums but without much progress.

\section{Community-based STI control programme of Bangladesh \\ Rural Advancement Committee (BRAC)}

BRAC began by launching a pilot project in early 1997 to raise community awareness about sexual illnesses and establish an effective system of case management of HIV infection (BRAC, 2000). Prior to that project, the community where BRAC began its campaign had very little idea about the transmission, prevention and treatment of STIs (BRAC and ICDDRB, 1999). The project included the promotion of knowledge about sexually transmitted illnesses, their mode of transmission, common symptoms, preventive measures and the sources of treatment. Information were disseminated through a variety of settings such as individual contacts at the households, small group meetings with both women and men, and counselling at the antenatal care centres (BRAC, 2000). The community health volunteers were employed to disseminate relevant STI-related information along with other health messages to the grass-roots level.

Earlier experience suggests that the acceptance of new information in the community differs widely according to the level of education and socio-economic characteristics of the population (Hadi, 2001). Education generally enhances the capacity to know more and creates a context to better understand. The women in Bangladesh have been very unfortunate as more than two thirds 
of the adult women never went to school. Alternative means of communication to reach the illiterate women were considered. Among these, NGO-led health forums were found viable media through which a large proportion of illiterate women could be reached. BRAC, therefore, decided to expand the STI control project by integrating with the micro-credit ${ }^{1}$ based development programme in 1998.

The micro-credit programme included not only the collateral-free credit for the rural poor women but a package of support services such as group meetings. skill training, basic literacy and primary health-care services. The credit programme-based health forums were conducted for the poor women in the villages by BRAC officials with the help of community health volunteers. To promote awareness of sexual illnesses among the community leaders, BRAC also organized village workshops and popular theatres for development. In addition, the community volunteers motivated rural women to visit health centres, satellite clinics, EPI centres and other health services. Earlier studies indicated that the progress of implementation of the ICPD recommendations was very slow and the achievement very little (Hadi, 1999). Given this backdrop, this study (a) assesses the awareness of transmission, symptom and prevention of sexual illnesses and (b) examines the contribution of women's education and their involvement in NGO forums in promoting STI knowledge in Bangladesh.

\section{Data and methods}

\section{Study design}

Assuming that the sexual issues are quite sensitive and that the group discussions with women in traditional communities would be difficult, open-ended in-depth interviews were conducted to collect information for this study. Three aspects of sexually transmitted infections (transmission, symptoms and prevention) were examined. Data for this study were collected from a demographic and health surveillance system ${ }^{2}$ covering 70 villages in 10 regions of Bangladesh where BRAC and a number of local NGOs had credit-based income generating activities. The surveillance system provided updated sampling frame from where a total of 1,663 adult women were selected at random. A test instrument was developed for the assessment of knowledge comprising four test items in transmission mechanism, four test items in symptoms and four items in preventive measures. A structured questionnaire was used to collect detailed information of the sociodemographic characteristics of women and their participation in NGO forum activities. The investigators had professional training and experience in conducting in-depth interviews. For this particular study, the investigators were sensitized about the potential problems in collecting informa- 
tion. Confidentiality of information was strictly followed. Data were collected in April 2000.

\section{Definition of variables}

Three outcome variables of STI knowledge viz. transmission, symptoms and prevention were estimated in this study. The knowledge items of transmission of the discases are: sexual activities with infected person, infected mother to child. blood transfusion and infected instruments. The knowledge of symptoms included: ulcer on sex organs, swelling of the thigh and uterus, yellowish secretion and pain in the lower abdomen. Finally, the knowledge of prevention covered: precaution during sex, condom use, choosing appropriate partner and following religious instructions.

\section{Model specification}

The contribution of women's education and credit forum on STI knowledge was assessed by logistic regression model. The main independent variables were the education of women and their participation in NGO forums. $E d$ ucation of women was categorized as illiterate, primary or less, and secondary or more. NGO forum participation was categorized as non-participation, participated for five years or less, participated for six years and over. Age was coded into 29 years and less and 30 years and over. Media exposure was dichotomized as exposed and not exposed to media. Occupation of husband ${ }^{3}$ was dichotomized as manual and non-manual labourer.

\section{Analytical procedure}

The analysis begins with a description of the background variables of the sample women. Secondly, the knowledge of STIs by the level of education and NGO forum participation was estimated. Thirdly, the three outcome variables such as transmission, symptoms and prevention were differentiated by sociodemographic factors. Then, the net impact of the education and NGO forum participation on the knowledge of sexual illnesses were examined by employing multivariate analysis. Finally, the probabilities of threc indicators of STI knowledge as outcomes of the effect of various combinations of factors were estimated. The multivariate analysis has been used to control the effects of confounding factors. It should be recognized that conducting research on such sensitive aspect as sexual illnesses was difficult. The approach followed in this study is cross-sectional. In other words, it does not allow the authors to draw definite conclusions about the contribution of education and NGO forum on the knowledge of sexual illnesses. 
Table 1. Profile of sample women

\begin{tabular}{|c|c|c|}
\hline Study variable & Percentage & Number \\
\hline \multicolumn{3}{|l|}{ Education: } \\
\hline $\begin{array}{l}\text { No education } \\
\text { Primary or less } \\
\text { Secondary or more }\end{array}$ & $\begin{array}{l}67.7 \\
18.2 \\
14.1\end{array}$ & $\begin{array}{r}1.126 \\
302 \\
235\end{array}$ \\
\hline \multicolumn{3}{|l|}{ NGO forum: } \\
\hline $\begin{array}{l}\text { No participation } \\
\text { Participated (between } 1 \text { and } 5 \text { years) } \\
\text { Participated (6 years and nore) }\end{array}$ & $\begin{array}{l}64.7 \\
21.5 \\
13.8\end{array}$ & $\begin{array}{r}1,076 \\
357 \\
230\end{array}$ \\
\hline \multicolumn{3}{|l|}{ Age (years): } \\
\hline $\begin{array}{l}29 \text { and below } \\
30 \text { and above }\end{array}$ & $\begin{array}{l}51.7 \\
48.3\end{array}$ & $\begin{array}{l}860 \\
803\end{array}$ \\
\hline \multicolumn{3}{|l|}{ Media exposure: } \\
\hline $\begin{array}{l}\text { Not exposed } \\
\text { Exposed }\end{array}$ & $\begin{array}{l}66.3 \\
33.2\end{array}$ & $\begin{array}{r}1.111 \\
552\end{array}$ \\
\hline \multicolumn{3}{|l|}{ Occupation of husband: } \\
\hline $\begin{array}{l}\text { Manual labour } \\
\text { Non-labourcr }\end{array}$ & $\begin{array}{l}40.6 \\
59.4\end{array}$ & $\begin{array}{l}675 \\
988\end{array}$ \\
\hline
\end{tabular}

\section{Profile of sample women.}

\section{Findings}

The differences in sociodemographic characteristics of sample women are shown in table 1 . More than two thirds $(67.7$ per cent) were illiterate while only 18.2 per cent went to primary school. The proportion that went to the secondary school was very small (14.1 per cent). More than a third of the women participated in NGO forum activities. Of them, 13.8 per cent were involved with NGO forum activities for six years or more. The sample women were quite young as more than a half ( 51.7 per cent) was aged less than 30 years. Exposure to media in rural settings in Bangladesh was very poor as only a third (33.2 per cent) of women had access to clectronic media. Nearly 40.6 per cent of the husbands of the sample women had to sell manual labour for their survival.

\section{Role of education and NGO forum participation on the awareness of sexual illnesses}

Although difficult, collecting information about sexual problems was not impossible (VanLandingham and others, 1994). The awareness regarding STIs and their associations with education of women and their involvement in NGO 
Table 2. Knowledge of the STIs by education and NGO forum participation

\begin{tabular}{|c|c|c|c|c|c|}
\hline \multirow[t]{2}{*}{ Knowledge of STI } & \multicolumn{2}{|c|}{ Education } & \multicolumn{2}{|c|}{ NGO forum } & \multirow[t]{2}{*}{ Al } \\
\hline & & cated & No & Participated & \\
\hline \multicolumn{6}{|l|}{ Transmission mechanism: } \\
\hline Sex with infected persons & 12.3 & 22.3 & 14.8 & 16.9 & 15.5 \\
\hline Use of infected equipınent & 1.0 & 1.9 & 1.2 & 1.4 & 1.3 \\
\hline Infected mother to newborn & 1.0 & 1.5 & 1.1 & 1.2 & 1.1 \\
\hline Blood transfusion & 0.2 & 1.1 & 0.6 & 0.3 & 0.5 \\
\hline Transmission (at least one) & 13.4 & 22.9 & 15.1 & 18.9 & 16.5 \\
\hline \multicolumn{6}{|l|}{ Symptoms: } \\
\hline Uleer on sex organs & 25.5 & 35.4 & 27.2 & 31.3 & 28.7 \\
\hline Swelling of the thigh and uterus & 5.9 & 8.9 & 6.8 & 7.0 & 6.9 \\
\hline Yellow secretion & 0.7 & 3.0 & 1.1 & 2.0 & 1.4 \\
\hline Pain and rashes & 0.9 & 1.5 & 1.2 & 0.9 & 1.1 \\
\hline Simptoms (at least one) & 28.5 & 37.8 & 30.4 & 33.6 & 31.5 \\
\hline \multicolumn{6}{|l|}{ Preventive measure: } \\
\hline Precaution during sex & 11.9 & 16.6 & 13.4 & 13.5 & 13.4 \\
\hline Choosing faithful partner & 11.0 & 15.8 & 12.0 & 13.6 & 12.6 \\
\hline Usc of condom & 3.3 & 6.1 & 4.6 & 3.6 & 4.2 \\
\hline Follow'ing religious tcachings & 2.2 & 2.4 & 2.0 & 2.7 & 2.3 \\
\hline Provention (at least once) & 26.3 & 37.4 & 29.2 & 31.2 & 29.9 \\
\hline
\end{tabular}

forum activities is presented in table 2. About 15.5 per cent women were aware that STI could be transnitted through engaging into sex with an infected person. The knowledge of the sexual intercourse as one of the modes of transmission was found in other studies as well (Brewis, 1992; Nuwaha and others, 1999). Only few women could recognize that sexually transmitted illnesses could be transmitted through blood transfusion ( 0.5 per cent), infected equipment ( 1.3 per cent) and from infected mothers to newborn (1.1 per cent). An aggregate measure of the knowledge of the transmission of infection was estimated if a woman could correctly mention at least one out of four items without prompting. About 16.5 per cent sample women could correctly identify at least one transmission mechanism of the sexually transmitted infections. This estimate was slightly higher than a study in 1994 where nearly 12 per cent of women had knowledge of the transmission of STI (Khan and others, 1997). Educated women and forum participants were significantly better aware than the illiterates and non-participants.

Compared to the transmission, the symptoms of diseases were better known. The irritation on sex organs as a symptom was known to nearly 28.7 per cent women. Only 6.9 per cent of rural women were aware the swelling of the thigh as a symptom of STI. Others such as swelling of the body (1.4 per cent) and rashes ( 1.1 per cent) were nearly unknown in the studied com- 
munities. At the aggregate level, about 31.5 per cent women were able to recognize at least one symptom of sexual discases. As found in the transmission mechanism, the performance in recognizing a symptom of sexual illness was better among educated than illiterate women and NGO forum participants than among non-participants.

The knowledge about the preventive measures of sexually transmitted diseases was very poor. While precaution during sexual intercourse (13.4 per cent) was largely recognized as the way to prevent STIs, choosing faithful partners was also considered a preventive measure by a significant proportion (12.6 per cent) of women. Use of condom was mentioned by only 4.2 per cent while following the religious instructions ( 2.3 per cent) was recognized by a smaller proportion. Nearly 29.9 per cent of sample women had the knowledge of at least one preventive measure against sexually transmitted diseases. When differentiated, the knowledge level was found to be positively associated with education and NGO participation of women.

\section{Knowledge of sexual illnesses: prevalence and socio-economic correlates}

The knowledge among women about sexual illnesses differed significantly with socio-economic factors (table 3 ). The education of women appeared to be significantly $(P<.01)$ associated with the knowledge of all three indicators such as transmission, symptoms and the prevention of sexually transmitted infections. The participation in NGO-led health forum also significantly raised the knowledge level. The knowledge about transmission, symptoms and the prevention of sexual illnesses appeared to increase $(P<0.01)$ with age of women as found in other studies (Khan and others, 1997). Exposure to media had a positive and significant $(P<0.01)$ impact in raising awareness of STI transmission, symptoms and the prevention among women. However, the awareness of these three indicators was much higher among the younger than older women $(P<0.05)$. The occupation of husband had no apparent impact on the knowledge of STIs except for the prevention of the disease.

\section{Factors predicting awareness of sexual illnesses: multivariate analysis}

The net effects of education and NGO forum participation in raising the knowledge of the three dimensions of STI controlling for the other factors are 
Table 3. Knowledge of sexual illnesses by sociodemographic characteristics

\begin{tabular}{|c|c|c|c|}
\hline \multirow[t]{2}{*}{ Sociodemographic factors } & \multicolumn{3}{|c|}{ Knowledge of sexual illnesses } \\
\hline & Transmission & Symptom & Prevention \\
\hline All & 16.5 & 31.5 & 29.9 \\
\hline \multicolumn{4}{|l|}{ Education: } \\
\hline No cducation & 13.4 & 28.5 & 26.3 \\
\hline Primary or less & 20.2 & 35.1 & 33.4 \\
\hline Sccondary or more & 26.4 & 41.3 & 42.6 \\
\hline Probahility $(P)$ value & $<.01$ & $<.01$ & $<.01$ \\
\hline \multicolumn{4}{|l|}{ NGO forum: } \\
\hline No participation & 15.1 & 30.4 & 29.2 \\
\hline Participated (between 1 and 5 years) & 16.8 & 30.5 & 29.7 \\
\hline Participated (6 years and more) & 22.2 & 38.3 & 33.5 \\
\hline Probability (P) value & $<.05$ & $<.10$ & $n s$ \\
\hline \multicolumn{4}{|l|}{ Media exposure: } \\
\hline Not exposed & 15.7 & 30.8 & 28.7 \\
\hline Exposed & 18.1 & 33.0 & 32.2 \\
\hline Prohahility $(P)$ value & $n s$ & $n s$ & $<.10$ \\
\hline \multicolumn{4}{|l|}{ Age (years): } \\
\hline 29 and bclow & 14.7 & 29.1 & 28.5 \\
\hline 30 and above & 18.4 & 34.1 & 31.4 \\
\hline Probahility $(P)$ value & $<05$ & $<.05$ & $n$. \\
\hline \multicolumn{4}{|l|}{ Occupation of husband: } \\
\hline Manual labour & 16.0 & 31.3 & 26.7 \\
\hline Non-labourer & 16.8 & 31.7 & 32.1 \\
\hline Prohability (P) value & $n . s$ & $n s$ & $<(0)$ \\
\hline
\end{tabular}

Note: $\quad \mathrm{ns}=$ Not significant.

presented in table 4. As expected, the role of education in improving the knowledge of sexual illnesses was significant as found in other studies (Khan and others, 1997). NGO forum participation had significant positive association with the knowledge of STIs although the role of education was more prominent than the forum participation when the effects of media exposure and other sociodemographic factors were controlled. Age was also strongly associated with the level of knowledge of sexual illnesses. The effects of other confounding factors such as media and occupation were not significant.

\section{Estimated probabilities of the knowledge of sexual illnesses}

The probabilities of the knowledge of sexually transmitted infections as outcomes of the effect of various combinations of predictors are shown in table 5. The knowledge of the modes of transmission is estimated maximum (0.45) among the sample women if they are highly educated, older (30 years and 
Table 4. Odds ratios for selected indicators of the knowledge of STIs

\begin{tabular}{|c|c|c|c|c|c|c|}
\hline \multirow[t]{2}{*}{ Predictor variable } & \multicolumn{2}{|c|}{ Transmission } & \multicolumn{2}{|c|}{ Symptom } & \multicolumn{2}{|c|}{ Prevention } \\
\hline & $\beta$ & $\begin{array}{l}\text { Odds } \\
\text { ratios }\end{array}$ & $\beta$ & $\begin{array}{l}\text { Odds } \\
\text { ratios }\end{array}$ & $\beta$ & $\begin{array}{l}\text { Odds } \\
\text { ratios }\end{array}$ \\
\hline \multicolumn{7}{|l|}{ Education: } \\
\hline No cducation & 0.00 & 1.00 & 0.00 & 1.00 & 0.00 & 1.00 \\
\hline Primary or less & 0.58 & $1.78^{\mathrm{c}}$ & 0.37 & $1.44^{\mathrm{c}}$ & 0.34 & $1.40^{b}$ \\
\hline Secondary or more & 1.02 & $2.79^{\mathrm{c}}$ & 0.69 & $2.00^{\mathrm{C}}$ & 0.74 & $2.09^{\mathrm{C}}$ \\
\hline \multicolumn{7}{|l|}{ NGO forum: } \\
\hline No participation & 0.00 & 1.00 & 0.00 & 1.00 & 0.00 & 1.00 \\
\hline Participated (between 1 and 5 years) & 0.15 & 1.16 & 0.01 & 1.01 & 0.09 & 1.09 \\
\hline Participated ( 6 ycars and morc) & 0.50 & $1.65^{\mathrm{c}}$ & 0.34 & $1.41^{b}$ & 0.25 & $1.29^{\mathrm{a}}$ \\
\hline \multicolumn{7}{|l|}{ Age (years): } \\
\hline 29 and below & 0.00 & 1.00 & 0.00 & 1.00 & 0.00 & 1.00 \\
\hline 30 and more & 0.26 & $1.30^{\mathrm{a}}$ & 0.22 & $1.25^{\mathrm{b}}$ & 0.14 & 1.15 \\
\hline \multicolumn{7}{|l|}{ Media: } \\
\hline Not exposed & 0.00 & 1.00 & 0.00 & 1.00 & 0.00 & 1.00 \\
\hline Exposed & 0.05 & 1.05 & 0.03 & 1.03 & 0.01 & 1.01 \\
\hline \multicolumn{7}{|l|}{ Occupation of husband: } \\
\hline Labour & 0.00 & 1.00 & 0.00 & 1.00 & 0.00 & 1.00 \\
\hline Non labour & 0.22 & 1.25 & 0.17 & 1.18 & -.09 & 1.00 \\
\hline Constant & -2.26 & & -1.19 & & -1.12 & \\
\hline-2 Log Likelihood & 1.447 .1 & & 2.042 .6 & & $1,996.9$ & \\
\hline$R$ squared & 0.041 & & 0.018 & & 0.019 & \\
\hline
\end{tabular}

over), participants of NGOs for many years, regularly exposed to media and not dependent on selling manual labour. If only the NGO participation reduces to less than five years while other conditions remain similar, the probability is expected to reduce to 0.36 . The probability declines further to 0.33 if the women do not participate in NGO programmes. If the level of education reduces to (between one and five years) while they are older, NGO participants for many years, exposed to media and not dependent on selling manual labour, the probability would be 0.23 . Data show that the probabilities consistently decline with the reduction of the role of education, NGO participation, age, media exposure and selling labour.

The probability of the knowledge of transmission is estimated minimum $(0.09)$ if the women are illiterate, younger (aged 29 and below), non-partici- 
Table 5. Estimated probabilities of the knowledge STIs by the combination of predictors

\begin{tabular}{|c|c|c|c|}
\hline \multirow[t]{2}{*}{ Combination of predictors } & \multicolumn{3}{|c|}{ Estimated probabilities } \\
\hline & Transmission & Symptom & Prevention \\
\hline $\begin{array}{l}\text { 1. Ilighly educated. older. NGO participint (6 } \\
\text { years and more), exposed to media and not } \\
\text { dependent on labour }\end{array}$ & 0.45 & 0.56 & 0.48 \\
\hline $\begin{array}{l}\text { 2.llighly educated, older. NCiO participant ( } 1 \text { to } \\
5 \text { years). cxposed to medial and not dependent } \\
\text { on labour }\end{array}$ & 0.36 & 0.48 & 0.44 \\
\hline $\begin{array}{l}\text { 3.Highly educated. older. no NCiO participa- } \\
\text { tion. Exposed to mediat and not dependent on } \\
\text { labour }\end{array}$ & 0.33 & 0.48 & 0.42 \\
\hline $\begin{array}{l}\text { f. Poorly educated, older. NGO participant of } \\
\text { years and nore). cxposed to media and not } \\
\text { dependent on labour }\end{array}$ & 0.34 & 0.44 & $0.3 x$ \\
\hline $\begin{array}{l}\text { 5. Illiterate, older. NGO participation }(6 \text { vears } \\
\text { and more). exposed to media and nol depend } \\
\text { onl labour }\end{array}$ & 0.23 & 0.39 & 0.31 \\
\hline $\begin{array}{l}\text { 6.Illiterate, older, VGiO participation il to } 5 \\
\text { years). exposed to needia and not dependent } \\
\text { on labour }\end{array}$ & 0.17 & 0.32 & 0.27 \\
\hline $\begin{array}{l}\text { 7.Illiterate, older. not participated in N(i), se- } \\
\text { posed to medial and not dependent on labour }\end{array}$ & 0.15 & 0.32 & 0.26 \\
\hline $\begin{array}{l}\text { S.lliteratle younger, no } N(i O) \text { participation, mol } \\
\text { exposed to media and dependent on labour }\end{array}$ & 0.119 & 0.23 & 0.24 \\
\hline
\end{tabular}

pants of NGOs. not exposed to media and dependent on selling labour. Nearly similar pattern is found in the probabilities of the knowledge of symptoms of diseases and their prevention. Data clearly suggest that the education of women and their participation in NGO-led forum were the main predictors of the knowledge of sexually transmitted infections in the rural areas of Bangladesh.

\section{Discussion}

Overall. the knowledge among women regarding the sexually transmitted infections was very poor. Although raising awareness about the transmission. prevention and cure of STls has received increased attention in other countries (Reddy and others, 1999), the women in Bangladesh seemed to have limited access to information about sexual illnesses and thus to be at risk of facing the catastrophe of HIV/AIDS epidemic (Cash and others, 2001). Education generally enhances the access and capacity to understand new ideas and innovations. 
It is, therefore, logical that educated women are more likely to accept the messages about sexual illnesses and their prevention than the illiterate ones. The participation in NGO-led communitywide dissemination of health messages has appeared to creatc an opportunity for the poor women to become aware of their own health problems (Hadi, 2001). Although the participants were largely homogeneous, they appeared to receive information in the light of their own values and behaved accordingly (Aubel and Sia. 1995).

It is not clearly known whether the Information, Education and Communication (IEC) activitics of the Government to promote sexually transmitted diseases have produced desired results because of the absence of systematic monitoring of these very activities. Given the poor prevalence of knowledge among women in the rural areas. it is reasonable to believe that the design and implementation of the dissemination activities were inadequate to reach most of the communities. While the national promotion of STI-related information required a comprehensive understanding of the epidemiology of sexual illnesses, the behavioural change components of the STI control programme focused essentially on the high-risk groups such as sex workers, vehicle-drivers, vendors, policemen and students. In addition. only a smaller section of the educated and economically better-off population who had aceess to both the electronic and print media was covered. No systematic and coordinated effort has been made to reach the larger population of the country. Sex education through school. although found very effective in many other countries. was not offered in Bangladesh (Islam and others. 1999). The poor women who live in remote villages have always been the most neglected group in receiving necessary health services. Although the Government has aceepted the ICPD principles of informing and providing necessary health services for women, the IEC activities focused on sexual illnesses appeared to have been poorly designed as most of the women remained unaware about sexual illnesses and their consequences.

Alternative approaches to reach underpriviledged women need to be explored. Inter-personal communication at the houschold level as an effective means of influencing normative beliefs and behaviour has been demonstrated through community-based family planning programme in Bangladesh. Non-governmental organizations (NGOs) have been trying to reach poor women through group-based meetings run by the community health volunteers. Such approaches have never been tried at the national level to disseminate sexual health-related information to women (Cash and others, 2001).

Open discussion about the sexual illnesses might be culturally inappropriate in the traditional communities. The approach to reach the target. therefore, should be sensitive to the beliefs and feelings of the community (Cash and others, 2001). Once the people in the community understands the problem, they 
are expected to be more likely to provide support for the safe and socially appropriate behaviour (Weller. 1995). It is believed that the integration of STI services into primary health-care system would not only make the services available and accessible to more people but would also help pcople sceking care by avoiding the potential stigma of going to a dedicated STI clinics (Bataringaya, 2000). Since the health centres in the rural areas provide a range of health services. the promotion of knowledge about sexual illnesses has never been identified as a priority. Thus, the recommended policy of integrating STI treatment with other services in the rural health entres in Bangladesh should be re-considered.

How can the issue of sexual illnesses be incorporated in the reproductive health programme in a more effective way? Coordinating and establishing a link between conmunity-based motivational activities and the services available in health facilities may produce the desired results. The community-based organizations should not only disseminate messages promoting safer sex and educate people about the potential risks of getting sexually transmitted infections. but they should also bring the sick women to the health facilities. Reorientation of health services providers including community health workers. traditional healers, private practitioners. pharmacists. social workers and others may be needed to effectively implement such initiatives (Sabatier. 1995).

The study argues that the necessary health education issues can be effectively incorporated in NGO-led development programmes in promoting prevention of sexually transmitted diseases among women. The control of sexual illnesses should be both a short-tern and long-term target. International agencies have long been providing financial support to promote STI awareness although the atailability of resources has not been adequate to routinely monitor the progress of work (Germainc. 1997). The dissemination of health messages through mass media, the observance of health campaigns. the use of community he:ilth educator and routine counselling services were important components of STI promotion. The conventional health information systems often fail to reach the poor as those programmes were targeted to the general public and not specifically designed for the poor. NGO forums. on the other hand, pay more attention to the need of the poor and their ability to understand. A strategy to integrate the promotion of knowledge of sexual illnesses within a development framework would be better able to address the health problems of women in rural communities. The paper concludes that NGO-led health forums can be an effective media in promoting STI-knowledge among the women in Bangladesh. 


\section{Endnotes}

Micro-credit programmes are designed primarily for the poor rural women. The programmes include a package of support services such as group formation, skill training, basic literacy and essential health care for the participating women. Not all women are eligible to participate in credit-based income generating activities. A woman is eligible provided her household owns less than 50 decimals of cultivable land and if any adult member of that family sells manual labour for at least 100 days in a year.

BRAC runs a demographic and health surveillance system covering mure than 70.000 people living in 70 villages spread over ten regions of Bangladesh where BRAC and other non-governmental organizations have credit-based income generating activities. The regions are selected as representative of the rural Bangladesh. In each region. BRAC operates a field research station to cover approximately 1.200 families in neighbouring six to eight villages. Field investigators routinely visit all households of the study villages and record relevant information on the registers. Information is then computerized in the central office of BRAC in Dhakit.

The concept of occupation of husband as labour is used by the NGOs in identifying the poor section of the community. A houschold is considered poor if any adult member of that houschold sells manual labour for at least 100 days a year.

\section{References}

Adekunle. A.O. and O.A. Ladipo (1992). "Reproductive tract infections in Nigeria: challenges for a fragile health infrastructure", in A. Germainc. K.K. Holmes. P. Piot and J.N. Wasserheit (eds.), Reproductive tract infections: Global Impact and Priorities for Women's Reproductive Heallh (New York. Plenum Press), p. 297-315.

Amirkhanian. Y.A.. J.A. Kelly and D.D. Issayev (2001). "AIDS knowledge, attitudes, and behaviour in Russia: results of a population-based, random-digit telephone survey in St Petersburg", International Journal of STD \& AIDS, 12:50-57

Aubel, J and J. Sia (1995). "Problem-posing IIIV/AIDS/STD education: Iearning = critical thinking". Sexual Health Exchange. No. 4.

Bataringaya, J. (2000). "Integrating HIV/AIDS into the work of development organisations: the experience of ActionAid". Sexual Health Exchange, No. 3.

Bangladesh Rural Advancement Commistec (BRAC) (2000). Annual Report of the Reproductive Health and Disease Control Programme, 2000), (Dhaka, Bangladesh Rural Advancement Committec). 
and International Center for Diarrhoeal Discases Research. Bangladesh (ICDDRB) (1999). Integrating sexual and reproductive health education into service delivery: $A$ programme for rural communities in Bangladesh. Report-in-Brief, (Washington, Promoting Women in Development).

Brewis, A.A. (1992). "Scxually-transmitted discase risk in a Micronesian atoll population". Healhh Transition Revien: 2(2):195-213

Cameron. D.. J. Simonsen and L. D'Costa (1989). "Female to male transmission of human immunodeficiency virus type 1: Risk factors for scroconversion in men", Lancet 2(8660):403-407.

Cash. K.. H. Nasreen. S. Khan. A. Bhuiya. M. Chowdhury and S. Chowdhury (2001). "Sexual health for rural Bangladeshi youti". Sexual Health Exchange. No. 1.

Castor. D.. P. Prabhakar, C. Furlonge. A. Rao and A. Brown (2002). "Determinants of gonorthoca infection among STD clinic attenders in Trinidad - 1: sociodemographic factors, knowledgc. risk perception and history of STD". International Journal of STD \& AIDS, 13(1):39-45.

Germaine. A. (1997). “Addressing the demographic imperative through health. empowerment, and rights: ICPD implementation in Bangladesh". Health Transition Review: 7(Supplement 4):33-36.

(incrmment of Bangladesh (199(a). National Policy on HIV/AIDS and STD Related Issues. (Dhaka. Ministry of Health and Family Welfarc. Govemment of the Pcople's Republic of Bangladesh).

(199(b). Final Draft. National Plan of Action of the ICPD Recommendations Prepared for the National Committec for Implementation of the ICPD-POA. (Dhaka. Ministry of Health and Family Welfare. Govenment of the People's Republic of Bangladesh).

(1994). National IIIV/AIDS Behaviour Change Communication Strategic Implementation Plan for Bangladesh. (Dhaka. Minisiry of Health and Family Welfarc. Govemment of the Pcople's Republic of Bangladesh).

IIadi. A. (1999). Implementation of the ICPD agenda: The case of reproductive health in Bangladesh. Paper presented at the Conference on ICPD. Concerned Women for Family Development, Dhaka, Bangladesh, 20 December.

(2001). "Promoting health knowledge through micro-credit programme: experience of BRAC, Bangladesh". Health Promotion International 16(3):219-27.

Hawkes. S.. L. Morison. S. Foster. K. Gausia, J. Chakraborty, R. Peeling and D. Mabey (1999) -Reproductive tract infections in women in low-income, low prevalence situations: assessment of syndromic management in Matlab. Bangladesh", Lancet, 354(9192):1776-1781.

Hillier. L.. D. Warr and B. Haste (1998). "Rural youth: HIV/STD knowledge levels and sources of information". Australian Journal of Rural Health, 6(1):18-26.

Hussain. M.A.. C.S. Rahman. N.G. Banik and N. Begum (1997). A Study on Prevalence of RTI/STDs in a Rural Area of Bangladesh. Dhaka. Save of Children (USA).

Istam. M.. A. Mitra. A. Mian and S. Vermund $(1999)$. "HIV/AIDS in Bangladesh: a national surveillance". International Journal of STD \& AIDS. 10:471-474. 
Khan. M.. M. Rahman. P. Khanam. B. Khuda. T. Kane and A. Ashraf (1997). "Awareness of sexually transmitted disease among women and service providers in rural Bangladesh". International Journal of STD \& AIDS, 8(11):688-696.

Nuwiha, F., E. Faxelid. S. Necma and B. Hojer (1999). "Lay people's perceptions of sexually transmitted infections in Uganda", International Journal of STD \& AIDS, 10:709-717.

Population Information Program (PIP) (1993). "Controlling Sexually Transmitted Diseases", Population Reports, 21(1), Series L, Number 9 (Baltimore, Population Information Programme).

Reddy. P.. A. Meycr-Weitz. B. Borne and (i. Kok (1999). "STD-related knowledge, beliefs and attitudes of Xhosa-speaking patients attending STD primary health-care clinics in South Africa", International Journal of STD \& AIDS, 10(6):392-400.

Sabatier. R. (1995). "Reorienting health and social scrvices", Sexual Health Exchange, No. 4.

UN:UDS (1998). The Public Health Approach to STD Control. UNAIDS Technical Update. UNAIDS Best Practice Collection (Geneva, UNAIDS).

United Nations (1995). Population and Development: Programme of Action, International Conference on Population and Development, Cairo, 5-13 September 1994, UN. ST/ESA/SER.A/149, New York, 1995.

VanLandingham. M.. J. Knodel. C. Saengtienchai and A. Pramualratana (199.4). "Aren't sexual issues supposed to be sensitive?". Health Transition Review, 4(1):85-90.

Wasserheit, J.N. (1992). "Epidemiological synergy: intertelationships between human immunodeficiency virus infection and other sexually transmitted diseases", Scxually Transmitted Discase.s. 19(2):61-77.

Weller. P.D. ( $(995)$. "Creating a referral network of health and social services". Sexual Health Exchange, No. 4.

Horld Bank (1993). World Development Report: Investing in Health (New York, Oxford University Press). 